\title{
The impact of COVID-19 on children with autism spectrum disorder
}

\author{
Rita Amorim, Sara Catarino, Pedro Miragaia, Cristina Ferreras, Victor Viana, Micaela Guardiano
}

Introduction. Children with autism spectrum disorder (ASD) often experience changing routines as a major challenge. For that reason, the need for adaptation during COVID-19 pandemic may have brought major problems to families with children with this pathology.

Aim. To explore how children with ASD and their parents experienced the social isolation during COVID-19 outbreak period.

Subjects and methods. We conducted an observational, cross-sectional and analytical study. We applied an anonymous questionnaire that included children's demographic and clinical characteristics, along with the impact of the COVID-19 outbreak in different aspects of family's daily life.

Results. Out of 99 questionnaires obtained, 43 were related to children with ASD and 56 to control group. Children with ASD predominantly had changes in behavior, while children from control group mostly found no changes. The majority of parents of ASD children reported a negative impact in emotion management against those in control group reporting mostly positive or no impact. Caregivers reported higher mean scores of anxiety levels in themselves than in their children. ASD children and their parents had higher levels of anxiety than healthy ones. In the group with ASD, children that did not maintain routines had higher mean levels of anxiety than children that maintained routines.

Conclusion. Our results show a potential important psychological impact of the COVID-19 pandemic not only in children with neurodevelopmental disorders but in their caregivers as well. Physicians must be prepared for the post-pandemic surveillance of mental disorders among families.

Key words. Adaptive behavior. Anxiety. ASD. COVID-19. Mental health. Stress.

\section{Introduction}

Autism spectrum disorder (ASD) is a neurodevelopmental disorder characterized by deficits in social communication and social interaction in addition to restricted and repetitive patterns of behavior and interests. Autism was first described by Leo Kanner in 1943, as a disorder in children who had problems relating to others and a high sensitivity to changes in their environment [1]. In 2013, Diagnostic and Statistical Manual of Mental Disorders, 5th ed. (DSM-5) created the umbrella diagnosis of ASD, consolidating four previously separate disorders: autistic disorder, Asperger syndrome, childhood disintegrative disorder, and pervasive developmental disorder not otherwise specified [2]. Although it appeared to be a rare disorder, the prevalence of ASD steadily increased [3-6].

The World Health Organization (WHO) declared the novel coronavirus (COVID-19) outbreak a global pandemic on March 11, 2020 [7]. In Portugal, children were forced to stay at home with school lockdown on March 13. Some of them started to get homework from their teachers on a daily basis, while others took classes using videocall. Furthermore, the Portuguese Government began broadcasting classes through television [8]. Despite the attempt to maintain the access to education universal, some children in need of special education were harmed by its absence. In addition, with the adaptation of the health system, children with neurodevelopmental diseases such as ASD saw their therapies suspended.

The COVID-19 pandemic has led families to adapt their lives including social isolation and work from home. The consequences of this outbreak on mental health are still unknown $[9,10]$. Change in routine is often a significant challenge for children with ASD $[11,12]$, and for that reason, families with children with ASD could be a vulnerable group to develop anxiety and mental abnormalities during quarantine.

Our study aims to explore how children with ASD and their parents experienced the social isolation in their homes during school closedown in the COVID-19 outbreak. We hypothesised that, during
Pediatric Department (R. Amorim, S. Catarino, P. Miragaia, C. Ferreras). Psychology Department (V. Viana). Neurodevelopmental Unit; Pediatric Department (M. Guardiano).

Centro Hospitalar e Universitário São João. Porto, Portugal.

Corresponding author: Rita Amorim MD. Pediatric Department. Centro Hospitalar e Universitário São João. Alameda Prof. Hernâni Monteiro. 4200-319 Porto (Portugal).

E-mail: rita.g.amorim@hotmail.com Accepted: 16.09.20.

Acknowledgment:

The authors would like to thank Linda Candeias and Ana Santos for their help in collecting data for this study.

How to cite this paper: Amorim R, Catarino S, Miragaia P, Ferreras C, Viana V, Guardiano M. The impact of COVID-19 on children with autism spectrum disorder. Rev Neurol 2020; 71: 285-91. doi: $10.33588 /$ rn. 7108.2020381

Versión española disponible en www.neurologia.com

(C) 2020 Revista de Neurología 
Table I. Questionnaire variables.

\begin{tabular}{|c|c|}
\hline \multirow{9}{*}{$\begin{array}{l}\text { Demographic } \\
\text { characteristics }\end{array}$} & 1. Gender (male/female) \\
\hline & 2. Age (in years) \\
\hline & 3. Mother and father age (in years) \\
\hline & 4. Mother and father education (less than 12 years; 12 years; university or higher) \\
\hline & 5. Mother and father job \\
\hline & 6. Household size (number of persons) \\
\hline & 7. Type of house \\
\hline & With/without outdoor space \\
\hline & Apartment/villa \\
\hline \multirow{13}{*}{$\begin{array}{l}\text { Personal } \\
\text { history }\end{array}$} & 8. Medical history \\
\hline & ADHD diagnosis \\
\hline & None/other diseases \\
\hline & 9. First day of quarantine \\
\hline & 10. How long is the child at home? (in days) \\
\hline & 11. Did the child already went out? (Yes/No) \\
\hline & If yes, how many times? \\
\hline & 12. Did school provide home classes? (Yes/No) \\
\hline & 13. Extracurricular activities before quarantine? (Yes/No) \\
\hline & If yes, did he/she maintain it? \\
\hline & 14. Did child maintain routines at home? (Yes/No) \\
\hline & 15. Were tasks at home given to the child? (Yes/No) \\
\hline & 16. Did child experienced or learnt something new? (Yes/No) \\
\hline \multirow{12}{*}{$\begin{array}{l}\text { Quarantine } \\
\text { details }\end{array}$} & 17. Did the child's behavior change? (Yes/No) \\
\hline & 18. What was the biggest challenge for the child? \\
\hline & 19. What was the biggest challenge for the caregiver? \\
\hline & 20. Impact of the quarantine in: \\
\hline & Learning (positive/negative/none) \\
\hline & Emotion management (positive/negative/none) \\
\hline & Personal development (positive/negative/none) \\
\hline & Relation with relatives (positive/negative/none) \\
\hline & 21. Child anxiety score (0 to 10 ) \\
\hline & 22. Caregivers/parents anxiety score (0 to 10 ) \\
\hline & 23. Child adaptation to quarantine score (0 to 10 ) \\
\hline & 24. Caregivers/parents adaptation to quarantine score (0 to 10) \\
\hline
\end{tabular}

quarantine, children with ASD would have more pronounced negative impact on different aspects of daily life. Furthermore, we expected that parents of children with ASD would report higher rates of stress and lower rates of adaptive capacity in regard to themselves and their children compared to parents of children without neurobehavioral disorders, during this time.

To the best of our knowledge, this is the first study focusing children with ASD and their parents, during the COVID-19 outbreak in Portugal.

\section{Subjects and methods}

We conducted an observational, cross-sectional and analytical study. During April 2020, a total of 99 parents of school age children accepted to participate in this study. We contacted parents of children with the diagnosis of ASD, as well as parents of children without neurodevelopment disease (control group) by telephone or by e-mail (online form). We applied an anonymous questionnaire with a total of 24 groups of questions (Table I) in order to explore children's demographic and clinical characteristics, along with the impact of the social isolation at home during COVID-19 outbreak in different aspects of theirs' and their parent's daily life. The variables 'anxiety levels' and 'adaptation to quarantine' were rated in a 0-10 scale, with higher score indicated maximum anxiety/total adaptation to quarantine. Categorical variables are presented as frequencies and percentages, and continuous variables as means and standard deviations. Comparison between ASD group with control group was performed using Student's $t$-test and Chi-square. All reported values of $p$ are two-tailed, with a $p$ value of 0.05 indicating statistical significance. Data analysis was performed using SPSS v. 24 software.

\section{Results}

Out of 99 questionnaires obtained, 43 were related to children diagnosed with ASD and 56 to children in the control group. Demographic characteristics of the sample are presented in table II. Mean age of the children participating in the study was $10.75 \pm$ 3.13 years, and $68.7 \%$ were male. Most of the parents were university educated $(62.9 \%$ for mothers and $61.1 \%$ for fathers), and children were in average in their 5 th grade ( $5.22 \pm 3.06$ years). Regarding the house type, they mostly lived in villas with outdoor space $(45.5 \%)$, with a mean household size of $3.71 \pm$ 
0.84 persons, and no statistically significant differences were found between both groups in these two variables $(p=0.420$ for house type and $p=0.924$ for household size).

Concerning the quarantine aspects (Table III), when the questionnaire was applied, on average, children with ASD were in quarantine day $43.86 \pm$ 9.25 and the children from control group were in quarantine day $34.21 \pm 6.55(p<0.001)$. During that period, most children $(60.6 \%)$ went out at least one time.

The great majority of children had previous extracurricular activities (79.8\%), and most of them suspended these activities during quarantine (75.9\%), without statistical significant difference between ASD and control groups (80.6\% in ASD vs. $72.9 \%$ in control; $p=0.433$ ).

Parents of children with ASD predominantly reported changes in behavior of their child (72.1\%), while parents of children from control group mostly found no changes (67.9\%), and differences between these groups were statistically different $(p<0.05)$. The causes for the behavior change mostly reported by parents of children with ASD were anxiety (41.7\%), irritability (16.7\%), obsession (11.1\%), hostility (5.6\%) and impulsivity (2.8\%).

In general, children maintained routines (83.8\%), were given tasks to do $(71.7 \%)$ and experienced or learnt something new (52.5\%), during the quarantine period.

We found no statistically significant differences, in both groups, between changes in behavior and the maintenance of routines $(p=0.191$ for ASD group and $p=0.550$ for control group) or task distribution $(p=0.642$ for ASD group and $p=0.596$ for control group).

Parents from both groups reported more negative than positive impact of quarantine in learning (46.5\% versus $14 \%$ in $\mathrm{ASD}$ and $50 \%$ versus $19.6 \%$ in controls), and we found no statistically significant differences between the groups $(p=0.572)$. We also found no statistically significant differences in the impact of quarantine in personal development ( $p=$ $0.518)$ and in family relations $(p=0.298)$.

On the other hand, the impact of the quarantine in emotion management was statistically different ( $p=0.020)$ between ASD and control group, with the majority of parents of ASD children reporting negative impact in emotion management (55.8\%) against those in control group reporting mostly positive impact or no impact of the quarantine in emotion management (71.4\%).

In what concerns to stress and anxiety, caregivers reported higher mean scores of anxiety levels in
Table II. Results concerning to demographic characteristics.

\begin{tabular}{|c|c|c|c|c|c|}
\hline & & All $(n=99)$ & $\operatorname{ASD}(n=43)$ & Control $(n=56)$ & $p$ \\
\hline \multicolumn{2}{|l|}{ Age (years) } & $10.75 \pm 3.13$ & $9.86 \pm 3.08$ & $11.43 \pm 3.03$ & 0.013 \\
\hline \multirow{2}{*}{ Gender } & Male & $68(68.7 \%)$ & $38(88.4 \%)$ & $30(53.6 \%)$ & \multirow{2}{*}{$<0.00$} \\
\hline & Female & $31(31.3 \%)$ & $5(11.6 \%)$ & $26(46.4 \%)$ & \\
\hline \multicolumn{2}{|c|}{ School grade (years) } & $5.22 \pm 3.07$ & $4.19 \pm 2.98$ & $6.02 \pm 2.92$ & 0.003 \\
\hline \multicolumn{2}{|c|}{ Mother age (years) } & $43.74 \pm 4.02$ & $43.16 \pm 4.76$ & $44.2 \pm 3.28$ & 0.206 \\
\hline \multirow{3}{*}{$\begin{array}{l}\text { Mother } \\
\text { education }\end{array}$} & $<12$ years & $17(17.2 \%)$ & $12(28 \%)$ & $5(9.3 \%)$ & \multirow{3}{*}{0.021} \\
\hline & 12 years & 19 (19.2\%) & $10(23.2 \%)$ & $9(16.7 \%)$ & \\
\hline & University & $61(61.6 \%)$ & $21(44.8 \%)$ & $40(74 \%)$ & \\
\hline \multicolumn{2}{|c|}{ Father age (years) } & $45.50 \pm 5.09$ & $45.83 \pm 6.02$ & $45.26 \pm 5.33$ & 0.597 \\
\hline \multirow{3}{*}{$\begin{array}{l}\text { Father } \\
\text { education }\end{array}$} & $<12$ years & $11(11.1 \%)$ & $8(20 \%)$ & $3(5.6 \%)$ & \multirow{3}{*}{0.082} \\
\hline & 12 years & $25(25.3 \%)$ & $12(30 \%)$ & $13(24 \%)$ & \\
\hline & University & $58(58.6 \%)$ & $20(50 \%)$ & $38(70.4 \%)$ & \\
\hline \multicolumn{2}{|c|}{ Household size } & $3.71 \pm 0.85$ & $3.70 \pm 0.83$ & $3.71 \pm 0.87$ & 0.924 \\
\hline \multirow{3}{*}{$\begin{array}{l}\text { Type of } \\
\text { habitation }\end{array}$} & Apartment with outdoor space & $28(28.3 \%)$ & $12(27.9 \%)$ & $16(28.6 \%)$ & \multirow{3}{*}{0.420} \\
\hline & Apartment without outdoor space & $26(26.3 \%)$ & $14(32.6 \%)$ & $12(21.4 \%)$ & \\
\hline & Villa with outdoor space & $45(45.5 \%)$ & 17 (39.5\%) & $28(50 \%)$ & \\
\hline
\end{tabular}

ASD: autism spectrum disorder.

themselves than in their children in both groups, with statistically significant differences $(p<0.05)$. ASD children had higher mean levels of anxiety imposed by the quarantine $(5.67 \pm 2.78)$, than healthy ones $(3.64 \pm 2.70)$ as well as the caregivers of ASD children $(7.37 \pm 2.37)$ versus those of the healthy group $(5.55 \pm 2.37)$. These differences were all statistically significant $(p<0.05)$.

With regard to the ability of adaptation to the quarantine, we found no statistically significant differences in mean scores either in children (7.49 \pm 2.03 in ASD group versus $7.32 \pm 2.64$ in control group; $p=0.723)$ or in their parents $(6.86 \pm 1.97$ in ASD group versus $6.75 \pm 2.38$ in control group; $p=0.806$ ).

In the group with $\mathrm{ASD}$, children that did not maintain routines had higher mean levels of anxiety than children that maintained routines, $(8.75 \pm$ 0.96 versus $5.36 \pm 2.71$ ), with statistically significant 
Table III. Results concerning to details of quarantine.

\begin{tabular}{|c|c|c|c|c|c|}
\hline & & All $(n=99)$ & $\operatorname{ASD}(n=43)$ & Control $(n=56)$ & $p$ \\
\hline Days in quarantine & & $38.35 \pm 9.14$ & $43.86 \pm 9.25$ & $34.21 \pm 6.55$ & $<0.001$ \\
\hline Went out during quarantine? & & $60(60.6 \%)$ & $29(67.4 \%)$ & $31(55.4 \%)$ & 0.223 \\
\hline How many times? (days) & & $2.66 \pm 5.09$ & $0.28 \pm 0.59$ & $4.53 \pm 6.41$ & $<0.001$ \\
\hline Extracurricular activity & & 79 (79.8\%) & $31(72.1 \%)$ & $48(85.7 \%)$ & 0.094 \\
\hline Maintain extracurricular activity & & $19(24.1 \%)$ & $6(19.4 \%)$ & $13(27.1 \%)$ & 0.433 \\
\hline Maintain routines & & $83(83.8 \%)$ & 39 (90.7\%) & $44(46.8 \%)$ & 0.104 \\
\hline Tasks at home & & 71 (71.7\%) & $30(69.8 \%)$ & $41(72.6 \%)$ & 0.706 \\
\hline New experience & & $52(52.5 \%)$ & $28(60.5 \%)$ & $26(46.4 \%)$ & \\
\hline Behaviour change & & $49(50.5 \%)$ & $31(72.1 \%)$ & $18(32.1 \%)$ & $<0.001$ \\
\hline \multirow{2}{*}{ Type of behaviour change } & Better & $11(22.4 \%)$ & $5(16.1 \%)$ & $6(33.3 \%)$ & \multirow{2}{*}{-0.164} \\
\hline & Worse & $38(77.6 \%)$ & $26(83.9 \%)$ & $12(66.7 \%)$ & \\
\hline \multirow{3}{*}{ Learning impact } & Positive & $17(17.2 \%)$ & $6(14 \%)$ & $11(19.6 \%)$ & \multirow{3}{*}{0.572} \\
\hline & Negative & $48(48.5 \%)$ & $20(46.5 \%)$ & $28(50 \%)$ & \\
\hline & None & $34(34.3 \%)$ & $17(39.5 \%)$ & $17(30.4 \%)$ & \\
\hline \multirow{3}{*}{ Impact in development } & Positive & $38(38.4 \%)$ & 15 (34.9\%) & $23(41.1 \%)$ & \multirow{3}{*}{0.518} \\
\hline & Negative & $33(33.3 \%)$ & $17(39.5 \%)$ & $16(28.6 \%)$ & \\
\hline & None & $28(28.3 \%)$ & $11(25.6 \%)$ & $17(30.4 \%)$ & \\
\hline \multirow{3}{*}{ Impact in emotions } & Positive & $31(31.3 \%)$ & $11(25.6 \%)$ & $20(35.7 \%)$ & \multirow{3}{*}{0.020} \\
\hline & Negative & $40(40.4 \%)$ & $24(55.8 \%)$ & $16(28.6 \%)$ & \\
\hline & None & $28(28.3 \%)$ & $8(18.6 \%)$ & $20(35.7 \%)$ & \\
\hline \multirow{3}{*}{ Impact in family relations } & Positive & $52(52.5 \%)$ & 19 (44.2\%) & 33 (58.9\%) & \multirow{3}{*}{0.298} \\
\hline & Negative & $14(14.1 \%)$ & $8(18.6 \%)$ & $6(10.7 \%)$ & \\
\hline & None & $33(33.3 \%)$ & $16(37.2 \%)$ & $17(30.4 \%)$ & \\
\hline Child anxiety score (0 to 10) & & $4.53 \pm 2.90$ & $5.67 \pm 2.78$ & $3.64 \pm 2.70$ & $<0.001$ \\
\hline Parents anxiety score (0 to 10) & & $6.34 \pm 2.53$ & $7.37 \pm 2.37$ & $5.55 \pm 2.37$ & $<0.001$ \\
\hline Child adaptation score (0 to 10 ) & & $7.39 \pm 2.38$ & $7.49 \pm 2.03$ & $7.32 \pm 2.64$ & 0.723 \\
\hline Parents adaptation score (0 to 10 & & $6.80 \pm 2.20$ & $6.86 \pm 1.97$ & $6.75 \pm 2.38$ & 0.806 \\
\hline
\end{tabular}

ASD: autism spectrum disorder. differences between the groups $(p<0.001)$. We also highlight that children that maintained routines had higher mean levels of adaptability to the quarantine period than the ones that did not maintain routines $(7.72 \pm 1.84$ versus $5.25 \pm 2.75)$, with statistically significant differences between the groups $(p=0.019)$. We found no statistically significant differences in the control group ( $p=0.095)$.

In the control group, children who experienced something new presented higher mean levels of adaptability to the quarantine than the ones that didn't learn or experience something new (8.08 \pm 2.29 vs $6.67 \pm 2.78$ ), with statistically significant differences between both groups $(p=0.045)$. We found no statistically significant differences in the group of children with ASD $(p=0.916)$.

Parents mentioned social isolation (41.4\%), not being able to play outside (13.1\%), routine changes (11.1\%), boredom (9.1\%) and remote school classes (7.1\%) as the main challenges for their children during the quarantine.

On the other hand, for the caregivers, child teaching (26.3\%), dealing with children behavior (26.3\%), maintaining routines (16.2\%), keeping children occupied (13.1\%) and social isolation (5.1\%) were the major challenges reported.

\section{Discussion}

School closedown and remote work were public health measures adopted in many countries in order to prevent the spread of the novel coronavirus during COVID-19 outbreak. This measures have had a psychological impact in many families around the world [13]. Some studies identified stressors during quarantine such as duration of quarantine, fear of infection, frustration and boredom, inadequate information, finances and stigma [14]. During this period, some children saw their routines being completely changed and they were called to respect rules that are not always understandable for them (i.e., disinfect your hands, do not touch your eyes or nose, and cover your mouth) [15].

There is considerable evidence that children with ASD are at intensified risk for anxiety, which can exacerbate ASD symptoms, and increase behavioral problems [16]. In our study, during school closedown period, children with ASD predominantly had changes in behavior, while most children in the control group maintained the previous behavior. Moreover, the causes for this behavior change reported by the parents were anxiety, irritability, obsession, hostility and impulsivity, all symptoms pre- 
viously described in the literature associated with this condition [16-18].

Emotion dysregulation is also a common issue experienced by individuals with ASD, and has been associated with maladaptive strategies [19]. Furthermore, anxiety and depression are among the most prevalent affective disorders in this children $[2,18,20,21]$. In fact, parents of our sample reported mostly a negative impact of quarantine in emotion management and higher mean levels of anxiety in ASD children against those in control group. On the other hand, the perception of the parents regarding the ability of adaptation to the quarantine was similar in both groups.

We also know that school demands and social engagement $[17,22,23]$ are stressors for children with ASD and taking this into account we could imagine that being at home, during quarantine, away from these challenges could comfort these children. However, during this period these children had to face a huge stressor for them: change of routines. Indeed, in our study, children with ASD that did not maintain routines had higher mean levels of anxiety, and on the other hand children that maintained routines had higher mean levels of adaptability to the quarantine. Furthermore, in the control group the maintenance of routines does not seems to influence anxiety levels or the ability to adapt to quarantine. These results supports the hypothesis that a common feature of children on the autism spectrum is obsession with routine, inflexibility and rituals and this individuals could be a risk group for mental health complications from COVID-19 [12,24,25].

Despite this big change in family's lives, caregivers of our study were concerned with maintaining routines, distributing tasks and providing new experiences for their children, maybe in an attempt to reduce the negative impact of the quarantine and to avoid chaos at home. Moreover, caregivers reported higher mean scores of anxiety levels in themselves than in their children in both groups, and pointed out interesting major challenges such as child teaching, dealing with children behavior, maintaining routines, keeping children occupied and social isolation. Parents of children with ASD experienced higher mean levels of anxiety compared to the parents of the control group. This finding is not surprising since the stress in parents of children with this condition is well documented in the literature, and has been attributed to the child's challenging behaviours [26-28].

During COVID-19 pandemic, several organizations such as WHO and UNICEF provided guid- ance for support families to stress management [2934]. Likewise, Narzisi [15] suggested tips for parents and caregivers of children with ASD to handle this condition during the COVID-19 'stay at home period' such as 'explain to your child what COVID-19 is', 'structure daily life activities', 'implement and share special interests with parents', and 'maintain contact with the school.'

Although the parents of children with ASD in our study do not perceive a negative impact on their children's personal development, which can be explained by the fact that it is too early to assess these consequences, the suspension of special education and therapies can have a devastating consequence on the development of this individuals. For that reason, and since early intervention is essential in this condition, is mandatory to assess the needs of these children as soon as possible at this time. On the other hand, with the changes in primary care well-child visits, many children have failed the routine developmental screening and there may be a dramatic decrease in the referral of children in need of multidisciplinary assessment. It is therefore of extreme importance to systematically apply neurodevelopment screening tools to all children in the post-pandemic period.

Nonetheless, our study has some limitations. All data were reported by parents rather than reported by children directly. Additionally, the autism subtype/severity level was not considered, and therefore children with high functioning autism were included in the same group as children with autism of other subtypes, with differences regarding cognitive and social functioning, which may have implications for the ability of adaptation strategies [35].

In conclusion, physicians should be alert to warning signs shown not only by risk groups but also by all families with regard to the impact of COVID-19 pandemic in mental health and we all must be prepared for the post-pandemic surveillance of mental disorders.

\section{References}

1. Kanner L. Autistic disturbances of affective contact. Nervous Child 1943; 2: 217-50.

2. American Psychiatric Association. Diagnostic and statistical manual of mental disorders, fifth edition (DSM-5). Washington, DC: American Psychiatric Association; 2013.

3. Boyle CA, Boulet S, Schieve LA, Cohen RA, Blumberg SJ, Yeargin-Allsopp M, et al. Trends in the prevalence of developmental disabilities in US children, 1997-2008. Pediatrics 2011; 127: 1034-42.

4. Elsabbagh M, Divan G, Koh YJ, Kim YS, Kauchali S, Marcín C, et al. Global prevalence of autism and other pervasive developmental disorders. Autism Res 2012; 5: 160-79.

5. Blenner S, Augustyn M. Is the prevalence of autism increasing in the United States? BMJ 2014; 348: 3088. 
6. Zylstra RG, Prater CD, Walthour AE, Aponte AF. Autism: why the rise in rates? J Fam Pract 2014; 63: 316-20.

7. WHO Director-General's opening remarks at the media briefing on COVID19 -March 2020. URL: https://www.who. int/dg/speeches/detail/who-director-general-s-openingremarks-at-the-media-briefing-on-covid-19---11-may-2020. [18.06.2020].

8. República Portuguesa. Comunicação enviada às escolas sobre a suspensão das atividades com alunos nas escolas de 16 de março a 13 de abril. URL: https://www.portugal.gov.pt/pt/ gc22/comunicacao/documento? $\mathrm{i}=$ comunicacao-enviada-asescolas-sobre-suspensao-das-atividades-com-alunos-nasescolas-de-16-de-marco-a-13-de-abril. [18.06.2020].

9. Shuja KH, Aqeel M, Jaffar A, Ahmed A. COVID-19 pandemic and impending global mental health implications. Psychiatr Danub 2020; 32: 32-5.

10. Khan S, Siddique R, Li1 H, Ali A, Shereen MA, Bashir N, et al. Impact of coronavirus outbreak on psychological health. J Glob Health 2020; 10: 010331.

11. Sanchack K, Thomas C. Autism spectrum disorder: primary care principles. Am Fam Physician 2016; 94: 972-9.

12. Baumer N, Spence S. Evaluation and management of the child with autism spectrum disorder. Continuum (Minneap Minn) 2018; 24: 248-75.

13. Pfefferbaum B, North CS. Mental health and the Covid-19 pandemic. N Engl J Med 2020; 383: 510-2.

14. Brooks SK, Webster RK, Smith L, Woodland L, Wessely S, Greenberg N, et al. The psychological impact of quarantine and how to reduce it: rapid review of the evidence. Lancet 2020; 395: 10227.

15. Narzisi A. Handle the autism spectrum condition during the coronavirus (COVID-19) stay at home period: ten tips for helping parents and caregivers of young children. Brain Sci 2020; 10: 207.

16. Postorino V, Kerns C, Vivanti G, Bradshaw J, Siracusano M, Mazzone L. Anxiety disorders and obsessive-compulsive disorder in individuals with autism spectrum disorder. Curr Psychiatry Rep 2018; 19: 92.

17. McVey A, Schiltz H, Haendel A, Dolan BK, Willar K, Pleiss SS, et al. Social difficulties in youth with autism with and without anxiety and ADHD symptoms. Autism Res 2018; 11: 1679-89.

18. Gordon-Lipkin E, Marvin AR, Law JK, Lipkin PH. Anxiety and mood disorder in children with autism spectrum disorder and ADHD. Pediatrics 2018; 141: e20171377.

19. Cai RY, Richdale AL, Uljarevic M, Dissanayake C, Samson AC. Emotion regulation in autism spectrum disorder: where we are and where we need to go. Autism Res 2018; 1: 962-78.

20. Vasa RA, Mazurek MO, Mahajan R, Bennet AE, Bernal MP, Nozzolillo AA, et al. Assessment and treatment of anxiety in youth with autism spectrum disorders. Pediatrics 2016; 137: e20152851J.
21. South M, Rodgers J. Sensory, emotional and cognitive contributions to anxiety in autism spectrum disorders. Front Hum Neurosci 2017; 11: 20.

22. Hwang S, Kim YS, Koh YJ, Leventhal B. Autism spectrum disorder and school bullying: who is the victim?, who is the perpetrator? J Autism Dev Disord 2018; 48: 225-38.

23. Rodda A, Estes A. Beyond social skills: supporting peer relationships and friendships for school-aged children with autism spectrum disorder. Semin Speech Lang 2018; 39: 2.

24. Eshraghi AA, Li C, Alessandri M, Messinger D, Eshraghi RS Mittal R, et al. COVID-19: overcoming the challenges faced by individuals with autism and their families. Lancet Psychiatry 2020; 7: 481-3.

25. Fletcher F, Foster-Owens M, Conduit R, Rinehart N, Riby D, Cornish KM. The development trajectory of parent-report and objective sleep profiles in autism spectrum disorder: associations with anxiety and bedtime routines. Autism 2016; 21: 493-503.

26. Bonis S. Stress and parents of children with autism: a review of literature. Issues Ment Health Nurs 2016; 37: 153-63.

27. Whitmore KW. Respite care and stress among caregivers of children with autism spectrum disorder: an integrative review. J Pediatr Nurs 2016; 31: 630-52.

28. Shepherd D, Landon J, Taylor S, Goedeke S. Coping and care-related stress in parents of a child with autism spectrum disorder. Anxiety Stress Coping 2018; 31: 277-90.

29. World Health Organization. Doing what matters in times of stress: an illustrated guide. URL: https://www.who.int/ publications-detail/9789240003927. [18.06.2020].

30. US Centers for Disease Control and Prevention (CDC). Coronavirus disease. Stress and coping. URL: https://www. cdc.gov/coronavirus/2019-ncov/daily-life-coping/managingstress-anxiety. [18.06.2020].

31. World Health Organization. Coronavirus disease (COVID-19) advice for the public: healthy parenting. URL: https://www. who.int/emergencies/diseases/novelcoronavirus-2019/advicefor-public/healthy-parenting. [18.06.2020].

32. UNICEF. Coronavirus disease: tips and guidance for families. URL: https://www.unicef.org/coronavirus/covid-19\#COVID19-explainers. [18.06.2020].

33. Healthy Children. Parenting \& COVID-19: 10 tips to help keep the calm at home. URL: https://www.healthychildren.org/ English/family-life/family-dynamics/communicationdiscipline/ Pages/Positive-Parenting-and-COVID-19_10-Tips.aspx. [18.06.2020]

34. Save the Children. Support for parenting during coronavirus. URL: https://www.savethechildren.net/support-parentingduring-coronavirus. [18.06.2020].

35. Giambattista C, Ventura P, Trerotoli P, Margari M, Palumbi R, Margari L. Subtyping the autism spectrum disorder: comparison of children with high functioning autism and Asperger syndrome. J Autism Dev Disord 2019; 49: 138-50.

\section{Impacto de la COVID-19 en niños con trastorno del espectro autista}

Introducción. Los niños con trastorno del espectro autista (TEA) a menudo experimentan el cambio de rutinas como un desafío importante. La necesidad de adaptación durante la pandemia por la COVID-19 puede haber causado problemas a estos niños.

Objetivo. Conocer cómo vivieron los niños con TEA y sus familias el aislamiento social durante la cuarentena.

Sujetos y métodos. Se realizó un estudio observacional, transversal y analítico. Se aplicó un cuestionario anónimo que incluía las características demográficas y clínicas de los niños, junto con el impacto que tuvo la pandemia en diferentes aspectos de la vida diaria de las familias.

Resultados. De los 99 cuestionarios obtenidos, 43 eran niños con TEA y 56 niños del grupo control. Los niños con TEA tuvieron predominantemente cambios en el comportamiento, a diferencia de los del grupo control. La mayoría de los niños con TEA tuvo un impacto negativo en el manejo de las emociones frente a los del grupo control, que expresaron un impacto mayoritariamente positivo/nulo. Los cuidadores puntuaron niveles de ansiedad más altos en ellos mismos que en 
sus hijos. Los niños con TEA y sus padres tenían niveles más altos de ansiedad que los controles. En el grupo con TEA, los niños que no mantuvieron las rutinas tuvieron niveles de ansiedad más altos.

Conclusión. Los resultados muestran un potencial impacto psicológico de la pandemia de la COVID-19 no sólo en los niños con trastornos del neurodesarrollo, sino también en sus cuidadores. Debe estarse preparado para la vigilancia de los trastornos mentales en las familias tras la pandemia de la COVID-19.

Palabras clave. Ansiedad. Comportamiento adaptativo. COVID-19. Estrés. Salud mental. TEA. 